\title{
Bond of love in the Novels of Khaled Hosseini
}

\author{
Dr. Silima Nanda \& Niloo Shokeen
}

\begin{abstract}
Khaled Hosseini the Afghan-American writer beautifully delves into the subtleties of human relationships. In his novels, Hosseini has expressed his concern about the wretched conditions of the people in general and women in particular who have been doubly marginalized-one by the society and the other within the four walls of their homes. Against the backdrop of such a fractured milieu, the strong factor that gives strength to the characters is the bond of love and loyalty as reflected in 'The Kite Runner', 'A Thousand Splendid Suns' and 'And the Mountains Echoed'. Hosseini makes it clear that these love stories are very much unlike the platonic sagas of romantic love between a man and a woman. They are not traditional, they are stories of love where "characters seek and are saved by love and human connection".(2003 interview). Their love is tried and tested amid difficult conditions and the characters are left to discover their individual paths of reuniting with their loved ones at their own peril. It is ultimately this longing for love that draws characters out of their isolation, gives them strength to transcend their limitations, to struggle with their vulnerabilities and perform devastating acts of self-sacrifice.
\end{abstract}

Key words: human relationships, milieu, love, strength, isolation.

Widely acclaimed as an Afghan-American writer, Khaled Hosseini recalls about the city where he was born, spent his childhood and observes that "Kabul was not the same always". Kabul as the capital of Afghanistan once had the pride of magnificent historical monuments, art, architecture, gardens and mouthwatering delicacies. A sudden twist of fate turned it into a caricature that would forever mourn a fall from grace. Hosseini recalls that in the past Kabul was not that "Islamic" city which it is referred to as today. Women in those times were free to choose and pursue their careers and worked in offices at par with the men. But with Afghanistan slowly falling into the tyrant hands of the Soviet Union, Mujahidin's and the Talibans, the plight of women started looming large along with the erosive socio-political conditions of the country. In his novels, Hosseini has expressed his concern about the wretched conditions of the people in general and women in particular who have been doubly marginalized -one by the society and the other within the four walls of their homes. It has been rightly observed by Brodsky that in the Afghan society, some view women as "half of men". Khaled Hosseini in one of his interviews in 2003 has candidly opined that "the treatment of women in some Muslim countries -including my own has been dismal". Against the backdrop of such a fractured milieu, the strong factor that gives strength to the characters is the bond of love and loyalty as reflected in 'The Kite Runner', 'A Thousand Splendid Suns' and 'And the Mountains Echoed'. Hosseini likes to treat his novels as love stories. But he makes it clear in his interview, that these love stories are very much unlike the platonic sagas of romantic love between a man and a woman. They are not traditional, they are stories of love where "characters seek and are saved by love and human connection". Their love is tried and tested amid difficult conditions and the characters are left to discover their individual paths of reuniting with their loved ones at their own peril. It is ultimately this longing for love that draws characters out of their isolation, gives them strength to transcend their limitations, to struggle with their vulnerabilities and perform acts of self-sacrifice.

\section{Intense Friendship: The kite Runner}

Hosseini likes to call his first book 'The Kite Runner' as a twisted tale of friendship. One doesn't need to be an Afghan to comprehend the tension between ethnic communities so marvellously summed up as the historical realism of Afghanistan from 1960's to the early $21^{\text {st }}$ century. Against this backdrop, the relationship of Amir and Hassan are portrayed which is one of intense friendship and loyalty. Amir belongs to the privileged class of the Pashtun whereas Hassan belongs to the subaltern class of the Hazaras "but we were kids who had learned to crawl together, and no history, ethnicity, society, or religion was going to change that either.'(p.22). The protagonist and Hassan are close friends; both of the same age though bound together in a master-servant relationship, Amir recalls that "I spent most of the first twelve years of my life playing with Hassan. Sometimes, my entire childhood seems like one long lazy summer day with Hassan, chasing each other between tangles of trees in my father's yard, playing hide-and-seek, cops and robbers, cowboys and Indians ..."(p.22) Hassan plays and reads out stories to him and is extremely loyal intently following orders as a servant. Amir remembers "Hassan never wanted to, but if I asked, he wouldn't deny me. Hassan never denied me anything". (P.3-4) It is Hassan who gives definition and shape to the concept of loyalty. Just before he goes 
off to retrieve the fallen blue kite, he tells Amir would do anything for him. "For you a thousand times over" (61)..Their friendship is a tapestry of complex relationships of love, guilt and retribution. Amir is fond of Hassan but evades his company to appease other Pashtun boys who poke his ribs for being friendly with an 'outcast'. This is explicitly revealed in the scene when Aseefa Pashtun friend of Amir taunts him by asking Amir how he could call Hassan a friend considering that he is a Hazara,: "Afghanistan is the land of Pashtuns, Aseef claims, ...we are the true Afghans, the pure Afghans, not this flat-nose here. His people pollute our Watan .They dirty our blood" (40). Amir loved his father the most, but was extremely green-eyed about Baba Jan's affection towards the servant boy. Baba Jan was critical about Amir's love for poetry and literature and desired him to be as chivalrous and sincere as Hassan. As a loyal follower Hassan was ready to do anything for his master. Once in a light hearted vein Amir asked Hassan whether he could eat dirt for his friend to which Hassan said "If you asked I would". (p.48).He proved his fidelity towards Amir time and again. Hassan defended Amir from neighbourhood boys' chidings and threatens them by taking a slingshot aimed at one of them for being rude with Amir. On his side, Amir feels thankful to Hassan but with an air of pride and starts seeing a rival in Hassan. He is repulsed by Baba Jan's predilection and decides to win a kite flying competition to win his admiration. This contest turns into a battlefield of loyalty and betrayal for the two friends. As Amir's kite soars in the clear sky Hassan runs to catch the last snapped kite for his master. In one of the alleys he is caught by the same bunch of impish boys. Aseef, the gang leader, and other boys rape Hassan. Amir watches the entire crime from behind a wall but doesn't rescue his friend. "I ran because I was a coward. I was afraid of Aseef and what he would do to me. It turned my back to the alley, to Hassan....Maybe Hassan was the price I had to pay, the lamb I had to slay" (p.68). The consciousness of his guilt of not saving Hassan from being sodomized by Aseef's gang haunts Amir for the entire lifetime and he is not able to mentally pardon himself. He recalls 'There was a monster in the lake .It had grabbed Hassan by the ankles, dragged him to the murky bottom. I was that monster. That was the night I became an insomniac" (p.75) Amir is full of complexities which prevent him from reacting. Probably Amir thinks that he is justified because Hassan has stolen away his place in Baba Jan's heart. For days Hassan keeps away from Amir, perhaps he knew that Amir had betrayed him when he most needed him. Amir on the other end pretends that he knows nothing of whatever happened on that fateful day. He is full of guilt but doesn't want to admit his fault. Amir is fearful that if Baba Jan comes to know about his cowardice then he would rebuke him even more. He confers another blow to their relationship when he blames Hassan of a theft and even implores Baba Jan to send Hassan away from their house. Hassan remains unresponsive as always and silently bears all the humiliation at his friend's hand. He leaves without uttering a word. Hassan's love for Amir and Baba Jan is full of grace and humility. He is indeed a Christ-like figure that only knows how to give love and doesn't expect anything in return. Soon, a Political crisis in Afghanistan forces Baba Jan and Amir to take refuge in the United States. But as Amir grows up into an adult he realises that he is affected by 'something' that he has left behind in Kabul. The guilt remains passive in his conscience. After his father's death he receives a call from an acquaintance who urges him to go back to Kabul as there was still scope for him to "be good again". He comes to know that Hassan was his half-brother and he and his wife had been killed by the Talibans, survived by a son named Sohrab. Amir is so full of self-reproach and disgust that he is determined to do all that he can to save Sohrab from Taliban's clutches. Amir realizes that the only way he can repay the debt of friendship is by saving Hassan's son from the clutches of the Talibans who were sexually abusing the boy.. He endures extreme physical violence as a symbol of repentance in the process of saving Sohrab. Coincidently Sohrab's deftness at the slingshot frees Amir from his tormentors in the same manner as previously Hassan had rescued Amir. Overwhelmed with love and empathy Amir adopts Sohrab as his son and becomes the symbol of his retribution. "For you a thousand times over" is what Hassan had said to Amir and now it is Amir who towards the end of the novel runs after the kite saying; "For you, a thousand times over" (p.323). Sohrab becomes the bridge of love and friendship between Amir and Hassan. .What Amir finally realizes is that true redemption comes from restoring one's own sense of self- worth and goodness as a human being.

\section{The Female Bonding}

From the story of intense friendship stretching beyond the peripheries of life and death we come across another peculiar love story between two women in his second novel 'A Thousand Splendid Suns'. This novel has so far been acclaimed as the most heart-breaking story which makes the reader cry at several points. Mariam and Laila are the co-wives of Rashid born two decades apart, one hailing from Herat, a remote part of Afghanistan and Laila belonging to an upper middle-class prosperous family. Separated by a gap of almost 19 years these two women find it difficult to adjust with each other in the beginning .Both suffer extreme violence and untold miseries by the patriarchs of the family-father and husband. Nana, discarded by her husband Jalil Khan, the rich businessman, gives birth to Mariam.in her life. The mother admonishes the daughter that "Learn this now and learn it well, my daughter: Like a compass needle that points north, a man's accusing finger always finds a woman, Always. You remember that, Mariam" (7). After marriage Mariam is forced to wear a Burqa 
because she is warned by her husband that "where I come from, a woman's face is her husband's business only."(p.75). Mariam had never before worn this veil and "the paddled headpiece felt tight and heavy on her skull and it was strange seeing the world through a mesh screen". (65) She fails to give Rasheed a son and it is this which brings Rasheed's fury over her. When Mariam suffers repeated miscarriages Rasheed vents out his inhumane brutality on this poor lady by making her to eat pebbles" he shoved two fingers in her mouth and pried it open, then forced the cold, hard pebbles into it"(94). Her marriage becomes her prison "She lived in fear of his shifting moods, his volatile temperament, his insistence on steering mundane exchanges down a confrontational path that, on occasion , he would resolve with punches, slaps, kicks and sometimes try to make amends with polluted apologies and sometimes not" (89)At first. Mariam is distressed over the fact that the girl whom she helped to revive from fatal injuries has trespassed into her house as her husband's second wife. She is filled with anger and jealousy at the sight of Laila and often enters into arguments with her. Few months later when Laila gives birth to a baby girl a vast change is brought about in both the women. A childless Mariam is so drawn towards the baby that she forgives Laila for the intrusion and there ensues between them a bond that lasts forever. Both of them discover that they are victims, not just of the violence of the war around them or of Afghanistan's patriarchal culture but also of Rasheed's temper and brutality. Once Mariam and Laila realize that they can help each other and endure their daily fear and humiliation the novel takes a different turn where these two ladies show resistance. Mariam turns to be a second mother to Aziza and both of them become very good friends "Mariam is in Laila's own heart, where she shines with the bursting radiance of a thousand suns" (402). When Laila is moaning in labor pain it is Mariam who takes on the responsibility. Despite all odds she reaches out to the doctor and tells her: "My daughter's water broke and the baby won't come out" and tends to her in that crucial period. There is none other such formal utterance of their feelings for each other yet it is reflected in that bond which they silently share. Mariam goes on to murder her husband in order to protect Laila. "the first time she was deciding the course of her own life" (341). Her killing of Rasheed gives her the status of a celebrity inside the Walayat's women's prison. With a single gesture, not only she liberates Laila from a cursed bondage to Rashid but even coerces her to begin a life afresh in a new country. Laila, on her arrival in Afghanistan, several years later goes to Mariam's grave in her birthplace to pay homage and even decides to name her third child as Mariam. The principal thing that echoes throughout this novel is the bond of love between the two women that becomes their strength to endure and retaliate against the ruthless patriarchal tradition.

\section{Web of Relationships}

With his third novel, "And the Mountains Echoed" Khaled Hosseini takes a leap into a web of relationships where we find several pairs of siblings brought together and separated by circumstances. The story revolves around a brother-sister duo named Abdullah and Pari who live in a poverty-stricken house along with their step-mother Parwana and a new born half-brother. Their father Saboor has decided to give away Pari to a childless rich couple living in the city of Kabul. The ten year old Abdullah has a slight inkling of his father's intentions but is too immature to stand up against him. He is more like a mother to the little girl than a brother. Separated from her brother at the age of three years, it is still easier for Pari to forget her past but for Abdullah the pain lasts forever till his memory is whitewashed due to an illness in his old age. Pari leaves Afghanistan, resides in Paris, marries her lover and has several children but still something about the past haunts her. She is intrigued about her early life and feels a void throughout her life as if she has left something behind. When she has matured into fifties only then the truth about her biological parents is disclosed. She takes along detour to Afghanistan, in order to find out about her brother and finally finds him in a sickly state in the United States. In this same novel, we find another sibling pair which is bound together in a complex web of emotions. Commenting on relationships as portrayed in his 'And the Mountains Echoed' Hosseini in his interview clearly says that "Having three brothers and a sister of my own, this specific aspect of family - siblingship —is one that I find thematically rich. The landscape of sibling ties is peppered with love, volatility, envy, and a host of other-and often conflicting - emotions that make it such fertile ground for fiction. I am interested in the manifest complexities of the relationship, its contradictions, its tensions, its inherent push-and-pull nature, and the early-life experiences that either rupture or intensify bonds between brothers and sisters. I am always drawn to these indelible and often transformative experiences that siblings share." Parwana and Masooma are twins. As nature has decided for them Parwana is stout and unattractive while Masooma is the most beautiful girl in the village. There emanates a love-hate relation between the two as they enter their adolescence and grow fond of the same man Saboor. Parwana goes to the extent of pushing her sister off the branch of a huge tree which turns Masooma into a breathing mound of an incapable body. Yet she neither discloses the incident to anyone nor seeks an apology from Parwana. As a gesture of repentance, Parwana devotes her life to Masooma's caretaking; right from feeding and cleaning her to changing her diapers. She forgets her fondness for Saboor till one day her brother brings to her a proposal to marry him. Masooma overhears their conversation and decides to liberate Parwana from her servitude. In the middle of a vast desert Masooma tells her "if you ever loved me, Parwana, if 
you were ever my true sister, then leave...have heart."(70) Parwana decides in her favour and starts walking towards a new life. She thinks "No one has to know. No one would. It would be her secret, one she would share with the mountains only...she has lived with secrets all her life...she doesn't look back anymore"; (P.71)despite hearing the wailings of her abandoned sister. She is a very complex person who is equally moved by love and fits of jealousy. "And the Mountains Echoed" is not about the story of a single person rather it is multidimensional. The same sets of events are described by different persons at different times in their personalised manner. Within this muddle of characters we find another brother-sister pair: Markos and Thalia. They are neither biological siblings nor cousins; they don't even live under the same roof. Thalia is an alter-ego of the globe-trotting Markos. He is afraid of getting trapped into relationships on a tiny island. He lives on sabbatical from one country to another and in his absence Thalia (the daughter abandoned by an actress mother who seeks to marry another lover out of her marriage) looks after his mother and performs her duties like a son. Markos is extremely fond of Thalia and grateful for taking his place in his mother's life. In addition to love between people, there is also a striking longing for the motherland which prevails in all his novels. There is always a going away and coming back to Afghanistan that surges the plot ahead. Whether it is 'The Kite Runner', 'A Thousand Splendid Suns' or 'And the Mountains Echoed' the characters revisit their motherland, aspire to rebuild their nation and revive old ties with their loved ones.

\section{Conclusion:}

Khaled Hosseini belongs to a country where a person's identity is defined by the family to which he belongs. This is reflected throughout all his works where family remains the central theme. He delves into a world of fathers and mothers, brothers and sisters, sons and daughters and friends and foes with all their manifest complexities and contradictions. Be it the father and son in 'The Kite Runner' or mother and daughter in 'And the Mountains Echoed', Hosseini explores the magnitude of emotions that the characters have for each other under demanding circumstances. He says: "I am keenly interested in the way parents and children love, disappoint and in the end honour each other". All his novels are filled with the joyful spirit of a typical afghan family whether in its motherland or in diaspora. In his interview Hosseini states that in his novels: "it is ultimately love that draws characters out of their isolation, that gives them the strength to transcend their own limitations, to expose their vulnerabilities, and to perform devastating acts of self-sacrifice".(2003).

\section{References:}

[1] Brodsky,Anne.(2004) With all our Strength: The Revolutionary Association of the Women of Afghanistan .New York; Taylor and Francis Books

[2] Morris,.P (1993). Literature and Feminism. Oxford: Blackwell publishers Ltd.

[3] Skaine,Robert J.C. Postcolonialism:A Very Short Introduction.2003.NewYork:OUP,2003

[4] Hoby,Hermoine."The Guardian".13 June 2013.

[5] HosseniKhaled(2003) The Kite Runner. Bloomsbury Publishing, Great Britain.

[6] Hosseni Khaled (2007). A ThousandSplendidSunsBloomsbury Publishing, Great Britain.

[7] Hosseni Khaled (2013) And The Mountains EchoedBloomsbury Publishing, Great Britain

[8] (http://www.theguardian.com/interview/author/Khaled-hosseni)

[9] (http://www.booksbrowse.com/author-interviews/full/index.cfm author/Khaled-hosseini)

[10] (http://www.femalefirst.co.uk/books/and-the-mountians-echoed-299208.) .Retrieved30 ${ }^{\text {th }}$ jan2014) 